\title{
Josh Bell
}

\section{Love Double-Wide (your love is Like A BAD tATtOo)}

Your love is like a bad tattoo.

I've done too much time

in this trailer park and I will

burn your double-wide down

except I'm lazy. Your love

is like a bad tattoo although

you put it on the back of my

eye. It starts "Ramona" and I

can't read the rest anymore.

I'm tired but I remember what it says. Something I won't

repeat is what. I said "love"

but meant a word that sounds

like "trigger" and means

"You're dead." Look it up

if you don't believe me.

Find it near "damn fool"

and "dear god" if there ever

was such a dictionary. And if

there was, you sure already

read it. I studied some Latin

strictly due to you: Semper

fidelis, semper idem, semper

paratus. Always faithful,

ready, and the same. Me or you,

what a question. Anymore 
I'm like some Ophelia who took

the other route, fat, drugged,

and gone to seed. Alive though.

Lounging in the wading pool

outside fair Hamlette's double-wide

in my best plastic sunglasses

and checking my periphery as if epiphanies might have to sneak right up on the likes of me. I'm in need of some coy flowers, a cocktail.

Somebody bring my notebook, too. I'll write one of my patented I didn't kill myself notes: Hello cruel world I'm still not leaving again, it's me.

Your love is like a bad tattoo deep on my superstructure. What monks scribble on bones in ossuaries, I imagine. My latest

affectation is pretending you are a house I'm haunting with my life. You don't think I'm pretending. Somebody bring me my hood. 